Syntax Literate : Jurnal Ilmiah Indonesia p-ISSN: 2541-0849 e-ISSN: 2548-1398

Vol. 5, No. 6, Juni 2020

\title{
PENGARUH ASUHAN KEFARMASIAN TERHADAP KUALITAS HIDUP PASIEN DIABETES MELITUS TIPE 2 DI DUA PUSKESMAS DAERAH JAKARTA TIMUR
}

\section{Yeshi Mayasari, Prih Sarnianto dan Yusi Anggriani}

Magister Farmasi Universitas Pancasila Jakarta

Email: yeshi.mayasari77@gmail.com,prih1488@gmail.com dan yusi1777@yahoo.com

\section{Abstract}

Pharmaceutical care is a series of disease management which is expected to improve the quality of life of patients with Diabetes Mellitus. The purpose of this study is to see that pharmaceutical care can improve adherence and quality of patients life for type $2 \mathrm{DM}$. This research with quasi-experimental non-equivalent control group pretest-posttest design. A sample of 160 type 2 DM patients consisted of 80 patients from Public Health Center of Cipayung sub-district (intervention group) 80 patients from Public Health Center of Kramat jati sub-district (control group). The total sampling method for the Prolanist group, and non-Prolanist groups by purposive sampling. Data was collected using questionnaire MMAS-8 (obedience), SF-36 (quality of life) and fasting blood glucose data (GDP) from laboratory of public health center. The characteristics of DM patients include a mean age is 58 years, female gender, high school education, housewife. Duration of $D M$ is 2-3 years old and obesity IMT value I. The result of Wilcoxon ( $p<0.05)$ there was an increase in adherence, quality of life, and controlled levels of GDP on intervention group. The result of the test of Mann-Whitney, there was an increase in adherence, quality of life, and controlled levels the consequences of pharmaceutical care in Non-Prolanist patients with value $(p<0,05)$. The result of The Spearman rho test indicate a positive relationship between the level of compliance and GDP control with quality of life. It can be concluded that pharmaceutical care can improve adherence, quality of life and control of GDP of the quality of patients life of DM 2 who are Prolanis and non-Prolanis participants, in certain public health center in East Jakarta.

Keywords: Pharmaceutical care, adherence, quality of life and diabetes mellitus

\footnotetext{
Abstrak

Asuhan kefarmasian merupakan rangkaian penatalaksanaan penyakit yang diharapkan dapat meningkatkan kualitas hidup pasien Diabetes Melitus. Tujuan penelitian ini untuk melihat asuhan kefarmasian dapat meningkatkan kepatuhan dan kualitas hidup pasien DM tipe 2. Penelitian dengan desain quasi experimental nonequivalent control group Pretest-Posttest. Sampel 160 pasien DM tipe 2 terdiri dari 80 pasien dari Puskesmas Kecamatan Cipayung [kelompok intervensi] dan 80 pasien Puskesmas Kecamatan Kramatjati [kelompok kontrol]. Metode total sampling untuk kelompok Prolanis, dan kelompok non-Prolanis secara purposive sampling. Data dikumpulkan menggunakan kuesioner MMAS-8 (kepatuhan), SF-36 (kualitas hidup)
} 
dan data gula darah puasa (GDP) dari laboratorium Puskesmas. Karakteristik pasien DM meliputi usia rata-rata 58 tahun, jenis kelamin perempuan, pendidikan SMA, ibu rumah tangga. Lama DM 2-3 tahun dan nilai IMT obesitas I. Hasil Uji Wilcoxon $(\mathrm{p}<0,05)$ terdapat petingkatan kepatuhan, kualitas hidup, dan keterkendalian kadar GDP pada kelompok intervensi. Hasil uji Mann-Whitney terdapat peningkatan kepatuhan, kualitas hidup dan keterkendalian kadar GDP akibat asuhan kefarmasian pada pasien Non-Prolanis dengan nilai $(\mathrm{p}<0,05)$. Hasil uji Spearman's rho menunjukkan adanya hubungan positif antara tingkat kepatuhan dan keterkendalian GDP dengan kualitas hidup. Dapat disimpulkan bahwa asuhan kefarmasian dapat meningkatkan kepatuhan, kualitas hidup dan keterkendalian GDP kualitas hidup pasien DM 2 peserta Prolanis dan non-Prolanis, pada puskesmas tertentu di Jakarta Timur.

Kata Kunci: Asuhan kefarmasian, kepatuhan, kualitas hidup dan diabetes melitus

\section{Pendahuluan}

Menurut data dari International of Diabetic Federation (IDF) 2014, diperkirakan 9,1 juta orang penduduk Indonesia didiagnosis sebagai penyandang DM. Dengan angka tersebut, Indonesia menempati peringkat ke-5 di dunia, atau naik dua peringkat dibandingkan pada 2013 yang menempati peringkat ke-7 di dunia dengan 7,6 juta orang penyandang DM (Perkeni, 2015).

Menurut Riset Kesehatan Dasar (Riskedas) 2013, prevalensi nasional DM di Indonesia berdasarkan diagnosis dokter atau gejala sebesar $2,1 \%$ dengan prevalensi tertinggi pada daerah Sulawesi Tengah $(3,7 \%)$ dan paling rendah pada daerah Jawa Barat $(0,5 \%)$. Sementara itu prevalensi DM di DKI Jakarta yang terdiagnosis sebesar 3,0\% (Kemenkes, 2013).

Diabetes mellitus merupakan penyakit menahun yang akan disandang seumur hidup, sehingga penyakit ini sangat berpengaruh terhadap kualitas hidup sumber daya manusia. Untuk meningkatkan kualitas hidup penyandang DM maka perlu dilakukan penatalaksanaan yang baik pada pasien DM. Apoteker mempunyai tanggung jawab penting dalam memaksimalkan pelayanan kefarmasian pada pasien. Hal yang dapat dilakukan apoteker di antaranya melaksanakan asuhan kefarmasian yaitu pengkajian dan pelayanan resep, pelayanan informasi obat (PIO), konseling, visite pasien (khusus pasien rawat inap), monitoring efek samping obat, pemantauan terapi obat dan evaluasi penggunaan obat. Dengan adanya asuhan kefarmasian diharapkan kepatuhan pasien terhadap pengobatan terjaga sehingga kadar glukosa darah dapat terkontrol dan kualitas hidup pasien meningkat (Kemenkes, 2013).

Penyakit ini disebabkan gangguan metabolism glukosa akibat kekurangan insulin baik secara absolu tmaupun relative, diabetes mellitus dapat diklasifikasikan berdasarkan penyebabnya, perjalanan klinik, dan terapinya, yaitu diabetes tipe 1, diabetes tipe 2 (RISKESDAS 2013), diabetes mellitus gestasional (GDM) serta tipe-tipe tertentu yang memiliki kaitan dengan keadaan lain (International Diabetes Federation, 2006) (Subandi, 2017). 
Menurut pusat data dan informasi kementerian kesehatan RI 2014, DKI Jakarta memiliki populasi pasien DM urutan kelima di Indonesia dengan jumlah 190.232 orang yang terdiagnosis oleh dokter (Perkeni, 2006). Di Puskesmas Cipayung dan di Puskesmas Kramatjati, penyakit diabetes melitus merupakan penyakit yang banyak diderita oleh pasien. Glukosa darah dan kualitas hidup pasien belum dapat dikontrol dengan baik, di kedua puskesmas tersebut dikarenakan belum ada asuhan kefarmasian yang optimal oleh seorang apoteker. Hal ini disebabkan karena tenaga apoteker yang bertanggung jawab terhadap asuhan kefarmasian di Puskesmas ini belum ada.

Berdasarkan uraian diatas, maka penulis melakukan penelitian di Puskesmas Cipayung sebagai kelompok yang mendapatkan asuhan kefarmasian (intervensi) dan di Puskesmas Kramatjati sebagai kelompok yang tidak mendapatkan asuhan kefarmasian (kontrol). Puskesmas Cipayung dan Puskesmas Kramatjati merupakan Puskesmas Kecamatan yang berada di Wilayah Jakarta Timur. Tujuan penelitian ini untuk mengetahui asuhan kefarmasia yang dilakukan terhadap pasien DM di Puskesmas Cipayung sebagai kelompok intervensi untuk meningkatkan kualitas hidup pasien DM.

\section{Metode Penelitian}

Penelitian ini menggunakan studi quasi exsperimental nonequivalent control group design yang bersifat prospektif. Penelitian ini dilakukan pada pasien DM prolanis dan non prolanis pada Mei 2018 - Agustus 2018. Data dalam penelitian ini merupakan data yang diperoleh dari pengisian kuesioner MMAS-8 dan SF-36 (Ware,J.E, Sherbourne,C.D, 1992) pasien DM yang melakukan kontrol di Puskesmas Cipayung dan Puskesmas Kramatjati Jakarta Timur. Penelitian ini menggunakan variabel dependen dan independen, sebagai variabel dependen adalah kualitas hidup pasien DM. Sementara itu, variabel independen dari penelitian ini adalah asuhan kefarmasian dalam bentuk pelayanan informasi obat (PIO) dan konseling. Pelayanan informasi obat (PIO) dan konseling merupakan variabel intervening yang keberadaannya merupakan faktor dimana variabel independen tidak berhubungan langsung dengan variabel dependen. Variabel independen ini adalah faktor yang akan mempengaruhi variabel dependen. Selain itu ada variabel coumpounding yang mungkin memiliki hubungan dengan kualitas hidup, yaitu jenis kelamin, usia, pendidikan, pekerjaan, lama menderita DM dihitung sejak terdiagnosis dan indeks masa tubuh (IMT).

\section{Hasil dan Pembahasan}

\section{Karakteristik Pasien}

Berdasarkan karakteristik sosio-demografi pasien DM tipe 2 dilihat dari median usia yang paling banyak pada usia 58 tahun pada kelompok kontrol nonProlanis yaitu 19 orang atau 47,5\%, pada kelompok intervensi Prolanis 20 orang atau $50 \%$, pada kelompok intervensi non-Prolanis sebanyak 20 orang atau 50\%, pada kelompok kontrol Prolanis 18 orang atau $45 \%$. Penelitian ini didukung oleh beberapa pendapat ahli bahwa dengan meningkatnya umur, maka intoleransi terhadap glukosa 
juga meningkat. Intoleransi glukosa pada lanjut usia ini sering dikaitkan dengan obesitas, aktivitas fisik yang kurang, berkurangnya masa otot, terjadi penurunan fungsi fisiologis, sehingga terjadi defisiensi sekresi insulin karena adanya gangguan pada sel- $\beta$ prankreas yang akan menyebabkan terjadinya resistensi insulin (PASARIBU, 2014).

Jenis kelamin pasien mayoritas perempuan yaitu 30 orang atau $75 \%$ dari kelompok kontrol maupun kelompok intervensi. Tingkat pendidikan terbanyak SMA yaitu kelompok intervensi Prolanis 15 orang atau 37,5\%, dan pada kelompok nonProlanis intervensi 16 orang atau $40 \%$. Karakteristik jenis kelamin terbanyak adalah perempuan. Hal ini disebabkan karena pada perempuan akan terjadi masa penurunan hormon estrogen dan progesteron terutama pada saat masa menopause. Hormon estrogen dan progesteron dapat meningkatkan respon insulin di dalam darah. Dikarenakan rendahnya hormon estrogen dan progesteron. Pada saat menopause terjadi, maka respon insulin akan menurun. Faktor lain yang mempengaruhi adalah banyaknya masa indeks tubuh perempuan yang tidak ideal, sehingga dapat menurunkan sensitifitas insulin. Hal tersebut yang menyebabkan wanita lebih banyak beresiko menderita DM tipe 2 dibandingkan dengan laki-laki (Meidikayanti \& Wahyuni, 2017).

Pada tingkat pengetahuan salah satunya dipengaruhi oleh tingkat pendidikan. Dengan pendidikan yang lebih tinggi seseorang dapat dengan mudah memahami sesuatu salah satunya mengenai penyakit diabetes dan efeknya terhadap kesehatan, sehingga berpengaruh terhadap kepatuhan kontrol gula darah, mengatasi gejala yang muncul dengan penanganan kesehatanan yang tepat serta mencegah terjadinya komplikasi. (Javanbakht, Abolhasani, Mashayekhi, \& Baradaran, 2012). Namun demikian, tidak menjamin bahwa pendidikan tinggi, pengalaman yang didapat tinggi juga karena dipengaruhi oleh faktor sosial budaya yang dapat mempengaruhi seseorang untuk melakukan tindakan berdasarkan pengalamannyaa Adat-istiadat, norma, dan dorongan dari orang-orang terdekat merupakan salah satu faktor yang membuat seseorang bertindak dalam mengambil suatu keputusan.

Dari karakteristik pekerjaan, sebagian besar sebagai ibu rumah tangga yaitu pada kelompok kontrol Prolanis 25 orang atau 62,5\%, kelompok kontrol nonProlanis 27 orang atau 67,5\%, kelompok intervensi Prolanis 27 orang atau 67,5\%, kelompok Intervensi non-Prolanis sebanyak 25 orang atau 62,5\%. Pekerjaan ibu rumah tangga dikategorikan dalam pekerjaan yang mempunyai aktivitas ringan. Aktifitas fisik merupakan salah yang berpengaruh terhadap peningkatan insulin dan kadar gula dalam darah. Seseorang yang aktifitas fisiknya ringan memiliki resiko 4,36 kali lebih besar menderita DM tipe 2 dibandingkan dengan orang yang mempunyai aktifitas sedang dan berat (Isnaini \& Ratnasari, 2018).

Lama DM paling banyak yaitu dengan rentang 2-3 tahun, untuk kelompok kontrol Prolanis 16 orang atau 40\%, kelompok kontrol non-Prolanis 19 orang atau $37,5 \%$, pada kelompok intervensi non-Prolanis 15 orang atau 37,5\%. Pada kelompok 
. Untuk pasien yang baru didiagnosis DM biasanya belum bisa menerima kalau dirinya menderita penyakit, sehingga dalam melaksanakan penatalaksanaan DM belum begitu baik dibandingkan dengan pasien yang sudah lebih lama menderita DM. Pasien yang sudah lama menderita DM biasanya sudah biasa dalam melakukan perawatan sehingga lebih berpengalaman dalam melakukan penatalaksanaan penyakitnya.

Untuk nilai Indeks Masa Tubuh (IMT) terbanyak adalah obesitas I yaitu pada kelompok non-Prolanis kontrol 13 orang atau 32,5\%, pada kelompok Prolanis intervensi 16 orang atau 40\%, Pada kelompok non-Prolanis intervensi 13 orang atau $32,5 \%$. Pada kelompok Prolanis kontrol terbanyak adalah nilai IMT berat badan normal yaitu 16 orang atau $40 \%$. Indeks Massa Tubuh (IMT) atau Body Mass Index (BMI) merupakan alat atau cara yang sederhana untuk memantau status gizi orang dewasa, khususnya yang berkaitan dengan kekurangan dan kelebihan berat badan. Berat badan kurang dapat meningkatkan resiko terhadap penyakit infeksi, sedangkan berat badan lebih akan meningkatkan resiko terhadap penyakit degeneratif salah satunya DM. Timbunan lemak bebas yang tinggi dapat menyebabkan meningkatnya up-take sel terhadap asam lemak bebas dan memacu oksidasi lemak yang pada akhirnya akan menghambat penggunaan glukosa dalam otot (Mc.Wright, 2008). Menurut D'adamo (2008) orang yang mengalami kelebihan berat badan, kadar leptin dalam tubuh akan meningkat. Leptin adalah hormon yang berhubungan dengan gen obesitas. Leptin berperan dalam hipotalamus untuk mengatur tingkat lemak tubuh, kemampuan untuk membakar lemak menjadi energi, dan rasa kenyang. Kadar leptin dalam plasma meningkat dengan meningkatnya berat badan. Leptin bekerja pada sistem saraf perifer dan pusat. Peran leptin terhadap terjadinya resistensi yaitu leptin menghambat fosforilasi insulin receptor substrate-1 (IRS) yang akibatnya dapat menghambat ambilan glukosa. Sehingga mengalami peningkatan kadar gula dalam darah (Adnan, Mulyati, \& Isworo, 2013).

\section{Pengaruh Asuhan Kefarmasian Terhadap Pasien Prolanis dan Non-Prolanis}

\section{a. Tingkat Kepatuhan}

Berdasarkan hasil Uji Wilcoxon diperoleh nilai p-value 0,761 ( $\mathrm{p}>0,05)$ artinya tidak ada perbedaan yang signifikan tingkat kepatuhan pada kelompok kontrol prolanis sebelum dan sesudah dilakukan test. Sementara pada kelompok intervensi Prolanis diperoleh nilai $\mathrm{p}$-value 0,000 ( $\mathrm{p}<0,05)$. Ini menunjukkan terdapat perbedaan tingkat kepatuhan yang signifikan setelah dilakukan asuhan kefarmasian. Untuk kelompok kontrol nilai tingkat kepatuhan sebelum dan sesudah dilakukan test tidak ada perbedaan yang signifikan dengan nilai yaitu 0,477 ( $p>0,05$ ). Sementara pada kelompok intervensi non-Prolanis terdapat perbedaan tingkat kepatuhan yang signifikan setelah dilakukan asuhan kefarmasian yaitu dengan nilai $0,000(\mathrm{p}<0,05)$. 
Tabel 1 Hasil Uji Wilcoxon Antara Kepatuhan Sebelum dan Sesudah Intervensi Farmasi Pada Pasien Prolanis dan non-Prolanis

\begin{tabular}{|c|c|c|c|c|c|c|c|c|c|c|c|c|}
\hline \multirow{3}{*}{ Kepatuhan } & \multicolumn{6}{|c|}{ Prolanis } & \multicolumn{6}{|c|}{ Non Prolanis } \\
\hline & \multicolumn{3}{|c|}{ Kontrol $(n=40)$} & \multicolumn{3}{|c|}{ Intervensi $(n=40)$} & \multicolumn{3}{|c|}{ Kontrol $(\mathrm{n}=40)$} & \multicolumn{3}{|c|}{ Intervensi $(\mathrm{n}=40)$} \\
\hline & Pre & Pos & Sig & Pre & Pos & $\operatorname{Sio}$ & Pre & Pos & Sio & Pre & Pos & $\mathrm{Si} \alpha$ \\
\hline Tinggi (8) & 5 & 0 & & 5 & 15 & & 3 & 1 & & 4 & 21 & \\
\hline Sedang (6 - ) & 22 & 30 & & 12 & 21 & & 22 & 23 & & 16 & 18 & \\
\hline Rendah $(<.6)$ & 13 & 10 & & 23 & 4 & & 15 & 16 & & 20 & 1 & \\
\hline Rata-rata & 6 & 6 & 0,76 & 5 & 7 & 0,00 & 5 & 5 & 0,45 & 5 & 7 & 0,00 \\
\hline
\end{tabular}

Hasil pre-test dengan tingkat kepatuhan tinggi pada kelompok kontrol non-Prolanis 3 orang, kemudian terjadi penurunan pada hasil post-test hanya satu orang. Sebelum dilakukan asuhan kefarmasian tingkat kepatuhan tinggi pada kelompok intervensi non-Prolanis sebanyak 4 orang. Kemudian setelah dilakukan intervensi jumlah responden dengan nilai tingkat kepatuhan tinggi dan terjadi peningkatan yang lebih tinggi terhadap kelompok intervensi non-Prolanis yaitu sebanyak 21 orang. Ada peningkatan nilai tingkat kepatuhan pada kelompok intervensi non-Prolanis sesudah diberikan intervensi yaitu sebesar 2, sedangkan pada kelompok kontrol non-Prolanis tidak terjadi perubahan. Pemberian asuhan kefarmasian memberikan dampak pada paien DM. Perbedaan nilai kepatuhan antara kelompok kontrol dan intervensi baik Prolanis maupun non-Prolanis menggambarkan bahwa asuhan kefarmasian berupa pelayanan informasi obat dan konseling yang diberikan farmasis kepada pasien prolanis DM tipe 2 meningkatkan tingkat kepatuhan pasien. Asuhan kefarmasian berupa pelayanan informasi obat dan konseling dapat meningkatkan pengetahuan pasien mengenai obat, cara penggunaan obat, mekanisme kerja obat, serta resiko menggunakan obat tidak sesuai aturan. Dengan meningkatnya pengetahuan pasien maka akan memberikan dampak yang lebih baik terhadap perilaku pasien untuk patuh dalam menjalani pengobatan. 


\section{b. Kadar Gula Darah Puasa}

Tabel 2 Hasil Uji Wilcoxon Antara GDP Sebelum dan Sesudah Intervensi Farmasi Pada Pasien Prolanis dan non-Prolanis

\begin{tabular}{|c|c|c|c|c|c|c|c|c|c|c|c|c|}
\hline \multirow{3}{*}{ GDP } & \multicolumn{6}{|c|}{ Prolanis } & \multicolumn{6}{|c|}{ Non Prolanis } \\
\hline & \multicolumn{3}{|c|}{ Kontrol $(n=40)$} & \multicolumn{3}{|c|}{ Intervensi $(\mathrm{n}=40)$} & \multicolumn{3}{|c|}{ Kontrol $(n=40)$} & \multicolumn{3}{|c|}{ Intervensi $(\mathrm{n}=40)$} \\
\hline & $\begin{array}{l}\text { Pre } \\
\text { test }\end{array}$ & $\begin{array}{l}\text { Pos } \\
\text { test }\end{array}$ & Sig & $\begin{array}{l}\text { Pre } \\
\text { test }\end{array}$ & $\begin{array}{l}\text { Pos } \\
\text { test }\end{array}$ & Sig & $\begin{array}{l}\text { Pre } \\
\text { test }\end{array}$ & $\begin{array}{l}\text { Pos } \\
\text { test }\end{array}$ & $\mathrm{Sig}$ & $\begin{array}{l}\text { Pre } \\
\text { test }\end{array}$ & $\begin{array}{l}\text { Pos } \\
\text { test }\end{array}$ & $\mathrm{Sig}$ \\
\hline $\begin{array}{l}\text { Normal } \\
(<100 \\
\mathrm{mg} / \mathrm{dl})\end{array}$ & 2 & 2 & & 1 & 5 & & 0 & 1 & & 0 & 22 & \\
\hline $\begin{array}{l}\text { Pra- } \\
\text { diabetes } \\
(100- \\
125 \mathrm{mg} \\
/ \mathrm{dl})\end{array}$ & 10 & 7 & & 3 & 16 & & 6 & 5 & & 35 & 18 & \\
\hline $\begin{array}{l}\text { Diabetes } \\
(\geq 126 \\
\mathrm{mg} / \mathrm{dl})\end{array}$ & 28 & 31 & & 36 & 19 & & 34 & 34 & & 5 & 0 & \\
\hline $\begin{array}{l}\text { Rata- } \\
\text { rata } \\
\text { Nilai } \\
\text { kadar } \\
\text { GDP }\end{array}$ & 163,68 & 168,63 & 0,66 & 189,45 & 132,40 & 0,00 & 161,48 & 178,35 & 0,037 & 204,45 & 101,98 & 0,00 \\
\hline
\end{tabular}

Gula Darah Puasa (GDP) merupakan kadar gula darah seseorang yang diukur atau diperiksa setelah menjalani puasa sekitar 10-12 jam (Kemenkes RI,2013). GDP dapat digunakan sebagai pedoman dalam diagnosis DM. Jika hasil pemeriksaan GDP $\geq 126 \mathrm{mg} / \mathrm{dl}$ dan terdapat keluhan khas DM, diagnosis DM dapat ditegakkan (Sustarni L Alam S Hadibroto I., 2010). Jumlah responden dengan kadar GDP normal pada kelompok kontrol Prolanis tidak terdapat perubahan, baik pre-test maupun post-test yaitu tetap sebanyak 2 orang. Sementara terjadi peningkatan jumlah responden dengan kadar GDP normal pada kelompok intervensi Prolanis sebelum dilakukan asuhan kefarmasian dari 1 orang responden kemudian meningkat menjadi 5 orang setelah dilakukan asuhan kefarmasian, pada kelompok intervensi non-Prolanis sebelum dilakukan asuhan kefarmasian tidak ada satu responden dengan kadar GDP normal, tetapi setelah dilakukan asuhan kefarmasian terjadi peningkatan yang sangat baik yaitu menjadi 22 orang. Sedangkan pada kelompok kontrol non-Prolanis terjadi peningkatan jumlah responden dengan kadar GDP normal hanya sedikit yaitu dari tidak ada menjadi 1 orang responden. Jumlah responden dengan kadar GDP pra-diabetes terjadi peningkatan hanya pada kelompok intervensi Prolanis yaitu dari 3 responden sebelum dilakukan intervensi, menjadi 16 orang setelah intervensi. Sedangkan pada kelompok lainnya terjadi penurunan jumlah responden dengan kadar GDP pra-diabetes. Pada kelompok Intervensi nonProlanis dari 35 orang sebelum intervensi menjadi 18 orang setelah intervensi, pada kelompok kontrol Prolanis dari 10 orang menjadi 7 orang dan pada kelompok kontrol non-Prolanis dari 6 orang menjadi 5 orang. Pada kategori 
responden dengan GDP kategori diabetes, tidak ada perubahan pada kelompok kontrol non-Prolanis yaitu dengan jumlah tetap yaitu sebanyak 34 orang, pada kelompok kontrol Prolanis terjadi peningkatan dari 28 orang menjadi 31 orang responden. Sedangkan pada kelompok Intervensi terjadi penurunan jumlah responden, pada kelompok intervensi Prolanis sebelum dilakukan intervensi sebanyak 36 orang dan sesudah dilakukan intervensi sebanyak 19 orang. Pada kelompok intervensi non-Prolanis dari jumlah responden 5 orang menjadi tidak ada sama sekali responden yang mempunyai kadar GDP dengan kategori diabetes.

Hasil penelitian menunjukkan bahwa asuhan kefarmasian berupa pelayanan informasi obat dan konseling mempunyai pengaruh terhadap penurunan kadar gula darah puasa. Untuk menjaga agar gula darah terkendali dengan baik, penderita DM tipe 2 memerlukan penatalaksanaan DM secara baik dan teratur. Apabila kadar gula darah tidak dapat dikendalikan dengan baik, maka kadar gula darah akan mengalami peningkatan dan penurunan secara tidak stabil sehingga dapat memicu terjadinya komplikasi (Anonim, 2014). Salah satu kadar gula darah yang dapat menggambarkan kondisi gula darah seseorang, khususnya penderita DM tipe 2 adalah kadar Gula Darah Puasa (GDP). GDP merupakan kadar gula darah seseorang yang diukur atau diperiksa setelah menjalani puasa sekitar 10-12 jam(Kemenkes RI,2013). GDP dapat digunakan sebagai pedoman dalam diagnosis DM. Jika hasil pemeriksaan GDP $\geq 126 \mathrm{mg} / \mathrm{dl}$ dan terdapat keluhan khas DM, diagnosis DM dapat ditegakkan (Adnan et al., 2013). Pada penelitian ini kadar gula darah puasa (GDP) responden pasien DM tipe 2 diukur untuk mengetahui kadar gula darah puasa pada kelompok kontrol dan kelompok Intervensi sebelum dilakukan asuhan kefarmasian berupa pelayanan informasi obat dan konseling (pretest) dan sesudah dilakukan asuhan kefarmasian (postest). 
c. Tingkat Kualitas Hidup

Tabel 3 Hasil Uji Wilcoxon Nilai Tingkat Kualitas Hidup Sebelum dan Sesudah Interfensi Farmasi Pada Pasien Prolanis dan Nonprolanis

\begin{tabular}{|c|c|c|c|c|c|c|c|c|c|c|c|c|}
\hline \multirow{3}{*}{$\begin{array}{l}\text { Kualitas } \\
\text { Hidup }\end{array}$} & \multicolumn{6}{|c|}{ Prolanis } & \multicolumn{6}{|c|}{ Non Prolanis } \\
\hline & \multicolumn{3}{|c|}{ Kontrol $(n=40)$} & \multicolumn{3}{|c|}{ Intervensi $(\mathrm{n}=40)$} & \multicolumn{3}{|c|}{ Kontrol $(n=40)$} & \multicolumn{3}{|c|}{ Intervensi $(\mathrm{n}=40)$} \\
\hline & $\begin{array}{l}\text { Pre } \\
\text { test }\end{array}$ & $\begin{array}{l}\text { Pos } \\
\text { test }\end{array}$ & Sig & $\begin{array}{l}\text { Pre } \\
\text { test }\end{array}$ & $\begin{array}{l}\text { Pos } \\
\text { test }\end{array}$ & Sig & $\begin{array}{l}\text { Pre } \\
\text { test }\end{array}$ & $\begin{array}{l}\text { Pos } \\
\text { test }\end{array}$ & Sig & $\begin{array}{l}\text { Pre } \\
\text { test }\end{array}$ & $\begin{array}{l}\text { Pos } \\
\text { test }\end{array}$ & Sig \\
\hline $\begin{array}{l}\text { Baik } \\
\text { sekali (76 } \\
-100)\end{array}$ & 0 & 0 & & 2 & 11 & & 0 & 0 & & 1 & 11 & \\
\hline $\begin{array}{l}\text { Baik (51 - } \\
75)\end{array}$ & 13 & 20 & & 22 & 27 & & 4 & 13 & & 22 & 27 & \\
\hline $\begin{array}{l}\text { Cukup (26 } \\
-50)\end{array}$ & 17 & 17 & & 16 & 2 & & 28 & 17 & & 17 & 2 & \\
\hline $\begin{array}{l}\text { Kurang (0 } \\
-25)\end{array}$ & 10 & 3 & & 0 & 0 & & 8 & 10 & & 0 & 0 & \\
\hline Rata-rata & 42,23 & 45,65 & $\mathbf{0 , 3 5}$ & 57,80 & 68,00 & 0,00 & 35,18 & 39,55 & 0,13 & 48,75 & 69,80 & $\mathbf{0 , 0 0}$ \\
\hline
\end{tabular}

Nilai Peningkatan kualitas hidup pada saat pre-test dan post-test dengan nilai baik sekali tidak terjadi perubahan pada kelompok kontrol non-Prolanis. Sedangkan pada kelompok intervensi terjadi peningkatan yaitu pada kelompok intervensi non-Prolanis dari 1 orang menjadi 11 orang. Nilai tingkat kualitas hidup dengan nilai baik saat pre-test dan post-test terjadi peningkatan pada kelompok prolanis kontrol dari 13 orang menjadi 20 orang, pada kelompok prolanis intervensi dari 22 orang menjadi 27 orang. Nilai tingkat kualitas hidup dengan nilai cukup pada saat pretest dan post-test tidak terjadi perubahan pada kelompok kontrol non-Prolanis yaitu tetap sebanyak 17 orang, sedangkan pada kelompok lainnya terjadi penurunan. Pada kelompok intervensi kontrol nonProlanis dari 28 orang menjadi 17 orang, dan pada kelompok non prolanis intervensi dari 17 orang menjadi 2 orang. Nilai tingkat kualitas hidup dengan nilai kurang pada saat pretest dan post-test pada kelompok intervensi nonProlanis tidak ada perubahan yaitu tidak ada seorang responden pun dengan nilai tingkat kualitas hidup kurang. Sedangkan pada kelompok kontrol non-Prolanis terjadi peningkatan dari 8 orang pada saat pre-test dan menjadi 10 orang pada saat post-test. Perbedaan nilai kualitas hidup antara kelompok intervensi dan kelompok kontrol yang signifikan menggambarkan bahwa asuhan kefarmasian yang diberikan farmasis kepada pasien DM tipe 2 kelompok intervensi baik Prolanis maupun non-Prolanis dapat meningkatkan kualitas hidup pasien tersebut.

\section{Hubungan Antara Tingkat Kepatuhan, Gula Darah Puasa, dan Kualitas Hidup}

Berdasarkan hasil Uji korelasi dengan Spearman's Rho Correlation, pada kelompok kontrol Prolanis diperoleh nilai sig $>0,05$. Korelasi nilai antara tingkat kualitas hidup dengan tingkat kepatuhan tidak signifikan yaitu dengan nilai sig 0,445 ( $p>0,05)$, korelasi nilai tingkat kepatuhan dan GDP dengan nilai sig 0,284 ( $>>0,05)$. 
Sedangkan untuk nilai korelasi tingkat kualitas hidup dan GDP terjadi perubahan yang signifikan yaitu $<0,05$ dengan nilai sig 0,000 , nilai tersebut menunjukkan adanya hubungan antara kualitas hidup dengan kadar GDP. Pada kelompok kontrol non-Prolanis untuk semua nilai korelasi nilai sig > 0,05, nilai korelasi tingkat kualitas hidup dan tingkat kepatuhan dengan nilai sig 0,834 ( $p>0,05)$, nilai korelasi tingkat kualitas hidup dan GDP 0,255 (>0,05), dan korelasi kepatuhan dan GDP diperoleh nilai sig $0,821(>0,05)$.

Pada kelompok Intervensi Prolanis untuk semua korelasi nilai sig $<0,05$, korelasi tingkat kualitas hidup dan tingkat kepatuhan nilai sig 0,001, korelasi tingkat kualitas hidup dan GDP dengan nilai sig 0,003, dan korelasi kepatuhan dan GDP dengan nilai sig 0,037. Pada kelompok Intervensi non-Prolanis untuk semua korelasi nilai sig $<0,05$, korelasi kualitas hidup dan kepatuhan nilai sig 0,038 , korelasi kualitas hidup dan GDP 0,003, dan korelasi kepatuhan dan GDP 0,002.

Tabel 4 Hasil Korelasi Pada Kelompok Kontrol Dan Kelompok Intervensi Dengan Uji Spearman's Rho Correlation

\begin{tabular}{|c|c|c|c|c|c|c|c|c|}
\hline \multirow{4}{*}{ Variabel } & \multicolumn{8}{|c|}{ Kelompok } \\
\hline & \multicolumn{4}{|c|}{ Kontrol } & \multicolumn{4}{|c|}{ Intervensi } \\
\hline & \multicolumn{2}{|c|}{$\begin{array}{l}\text { Prolanis } \\
(n=40)\end{array}$} & \multicolumn{2}{|c|}{$\begin{array}{l}\text { Nonprolanis } \\
(n=40)\end{array}$} & \multicolumn{2}{|c|}{$\begin{array}{l}\text { Prolanis } \\
(\mathrm{n}=40)\end{array}$} & \multicolumn{2}{|c|}{$\begin{array}{c}\text { Nonprolanis } \\
(\mathrm{n}=40)\end{array}$} \\
\hline & $\begin{array}{c}\text { Nilai } \\
\text { korelasi }\end{array}$ & Sig. & $\begin{array}{c}\text { Nilai } \\
\text { korelasi }\end{array}$ & Sig. & $\begin{array}{c}\text { Nilai } \\
\text { korelasi }\end{array}$ & Sig. & $\begin{array}{c}\text { Nilai } \\
\text { korelasi }\end{array}$ & Sig. \\
\hline $\begin{array}{l}\text { Kualitas hidup } \\
\text { Kepatuhan }\end{array}$ & 0,124 & 0,445 & $-0,030$ & 0,834 & 0,495 & 0,001 & 0,330 & $\mathbf{0 , 0 3 8}$ \\
\hline $\begin{array}{l}\text { Kualitas hidup } \\
\text { GDP }\end{array}$ & 0,493 & 0,001 & 0,184 & 0,255 & 0,452 & 0,003 & 0,460 & 0,003 \\
\hline
\end{tabular}

Diabetes melitus merupakan penyakit menahun yang akan disandang seumur hidup, sehingga penyakit ini sangat berpengaruh terhadap kualitas hidup sumber daya manusia. Untuk meningkatkan kualitas hidup penyandang DM maka perlu dilakukan penatalaksanaan yang baik pada pasien DM yang mempunyai tujuan menghilangkan keluhan DM, memperbaiki kualitas hidup, mengurangi resiko komplikasi akut, mencegah dan menghambat progresivitas penyulit mikroangiopati dan makroangiopati, serta turunnya morbiditas dan mortalitas diabetes melitus (Perkeni, 2015). Pada kelompok Intervensi baik Prolanis maupun non-Prolanis dari hasil korelasi menunjukkan bahwa tingkat kepatuhan pasien berpengaruh signifikan terhadap GDP, dan kualitas hidup. Tingkat kepatuhan pasien meningkat dikarenakan pengetahuan pasien tentang penyakit, pengobatannya serta efek-efek yang ditimbulkan dari penyakit meningkat. Hal itu akan mempengaruhi hasil GDP, dan kualitas hidup dari pasien tersebut.

Pada penelitian ini walaupun kebanyakan pasiennya berlatar belakang Sekolah Menengah Atas (SMA) dengan pekerjaan ibu rumah tangga tetapi hasil terapi dan kualitas hidup mereka meningkat. Hal ini menunjukkan pentingnya farmasis ikut 
berperan aktif memberikan asuhan kefarmasian yang optimal sehingga mempengaruhi pengetahuan dan cara pandang mereka tentang kesehatan khususnya tentang penyakit diabetes mellitus yang dideritanya dan selanjutnya meningkatkan kepatuhan, sehingga keberhasilan terapi dan kualitas hidup yang baik pun akan tercapai.

\section{Kesimpulan}

Kriteria pasien Prolanis dan non-Prolanis diabetes mellitus tipe 2 pada kelompok intervensi maupun pada kelompok kontrol hampir sama, yaitu usia mayoritas 50-59 tahun dengan nilai median 58 tahun, jenis kelamin perempuan lebih dominan dibandingkan dengan laki-laki, tingkat pendidikan terbanyak Sekolah Menengah Atas, pekerjaan terbanyak sebagai ibu rumah tangga, lama mengalami DM 2-3 tahun, dan rata-rata IMT dengan nilai obesitas I. Asuhan Kefarmasian berupa pelayanan informasi obat dan konseling pada kelompok intervensi baik pada kelompok Prolanis maupun non-Prolanis memberikan pengaruh yang signifikan terhadap kepatuhan, GDP, dan kualitas hidup, sedangkan pada kelompok kontrol tidak memberikan perbedaan yang signifikan terhadap kepatuhan, GDP, dan kualitas hidup sebelum dan sesudah dilakukan penelitian. Adanya hubungan antara kepatuhan, GDP, dan kualitas hidup pada kelompok intervensi, sedangkan pada kelompok kontrol tidak ada hubungan antara kepatuhan, GDP, dan kualitas hidup. Hal ini menunjukkan, bahwa asuhan kefarmasian berupa pelayanan informasi obat dan konseling yang diberikan farmasis dapat meningkatkan kepatuhan sehingga tercapai keterkendalian GDP dan kualitas hidup yang optimal. Saran penulis perlu adanya penelitian lebih lanjut pada penelitian ini, yaitu dengan asuhan kefarmasian lainnya mengenai monitoring efek samping obat, pemantauan terapi obat, evaluasi penggunaan obat dan ronde/visite baik pada pasien rawat jalan maupun pasien rawat inap sehingga pengaruh peranan farmasis dalam peningkatan kepatuhan, keterkendalian GDP dan kualitas hidup yang optimal pada pasien DM tipe 2 dapat terlihat lebih signifikan. 
Yeshi Mayasari, Prih Sarnianto dan Yusi Anggriani

\section{BIBLIOGRAFI}

Adnan, Miftahul, Mulyati, Tatik, \& Isworo, Joko Teguh. (2013). Hubungan Indeks Massa Tubuh (IMT) dengan kadar gula darah penderita diabetes mellitus (DM) tipe 2 rawat jalan di RS Tugurejo Semarang. Jurnal Gizi, 2(1).

Isnaini, Nur, \& Ratnasari, Ratnasari. (2018). Faktor risiko mempengaruhi kejadian Diabetes mellitus tipe dua. Jurnal Kebidanan Dan Keperawatan Aisyiyah, 14(1), 59-68.

Javanbakht, Mehdi, Abolhasani, Farid, Mashayekhi, Atefeh, \& Baradaran, Hamid R. (2012). Health related quality of life in patients with type 2 diabetes mellitus in Iran: a national survey. PloS One, 7(8).

Kemenkes, R. I. (2013). Balitbangkes. 2013. Laporan Hasil Riset Kesehatan Dasar (Riskesdas) Indonesia Tahun 2007.

Meidikayanti, Wulan, \& Wahyuni, Chatarian Umbul. (2017). Hubungan dukungan keluarga dengan kualitas hidup Diabetes melitus tipe 2 di puskesmas pademawu. Jurnal Berkala Epidemiologi, 5(2), 240-252.

Pasaribu, Sumitro. (2014). Distribusi Umur, Jenis Kelamin, Tingkat Pendidikan, Pekerjaan Dan Jenis Komplikasi Pada Penderita Dm Tipe 2 Dengan Komplikasi Yang Dirawat Inap Di RSUD Dr. Pirngadi Medan Tahun 2012.

Subandi, Endang. (2017). Pengaruh Senam Diabetes Perhadap Penurunan Kadar Gula Darah Pada Pasien Diabetes Mellitus Di Upt Puskesmas Mundu Kabupaten Cirebon Tahun 2017. Syntax Literate; Jurnal Ilmiah Indonesia, 2(7), 53-68. 